\title{
DETERMINAN INTENSI AUDITOR MELAKUKAN TINDAKAN WHISTLE-BLOWING DENGAN PERLINDUNGAN HUKUM SEBAGAI VARIABEL MODERASI
}

\author{
M. Wahyuddin Abdullah \\ tosir_wahyu@yahoo.com \\ Hasma \\ Universitas Islam Negeri (UIN) Alauddin Makassar
}

\begin{abstract}
This research aims to examine factor influence organizational commitment, personal cost of reporting, seriousness of wrongdoing and professionalism to the intention auditor whistle-blowing action with legal protection as a moderating variable. This research is quantitative descriptive approach. The population in this study were all auditors working in the South Sulawesi Provincial Inspectorate with purposive sampling technique. The data used in the research is the primary data collected through a questionnaire survey directly. Analysis of data using multiple linear regression analysis and multiple linear regression analysis to test the absolute value of the difference to the hypothesis of organizational commitment, personal cost of reporting, seriousness of wrongdoing and professionalism are moderated by legal protection. The results of the study with multiple linear regression analysis showed that seriousness of wrongdoing and professionalism positive and significant effect whereas organizational commitment and personal cost of reporting and no significant negative effect to the intention of auditors act of whistle-blowing. Analysis of moderating variables to approach the absolute value of the difference indicates that legal protection is only able to moderate seriousness of wrongdoing and not able to moderate organizational commitment, personal cost of reporting and professional attitude to the intention auditor act of whistle-blowing.
\end{abstract}

Key words: whistle-blowing intention, organizational commitment, personal cost of reporting, seriousness of wrongdoing, professionalism, legal protection

\begin{abstract}
ABSTRAK
Penelitian ini bertujuan untuk menguji pengaruh faktor komitmen organisasi, personal cost of reporting, tingkat keseriusan kecurangan, dan sikap profesionalisme terhadap intensi auditor melakukan tindakan whistle-blowing dengan perlindungan hukum sebagai variabel moderasi. Penelitian ini merupakan penelitian kuantitatif dengan pendekatan deskriptif. Populasi dalam penelitian ini adalah seluruh auditor yang bekerja di lingkungan Inspektorat Provinsi Sulawesi Selatan dengan teknik pengambilan sampel purposive sampling. Data yang digunakan dalam penelitian merupakan data primer yang dikumpulkan melalui survei kuesioner secara langsung. Analisis data menggunakan analisis regresi linear berganda dan analisis regresi linear berganda dengan uji nilai selisih mutlak untuk hipotesis komitmen organisasi, personal cost of reporting, tingkat keseriusan kecurangan, dan sikap profesionalisme yang dimoderasi oleh perlindungan hukum. Hasil penelitian dengan analisis regresi linear berganda menunjukkan bahwa tingkat keseriusan kecurangan dan sikap profesionalisme berpengaruh positif dan signifikan sedangkan komitmen organisasi dan personal cost of reporting berpengaruh negatif dan tidak signifikan terhadap intensi auditor melakukan tindakan whistle-blowing. Analisis variabel moderating dengan pendekatan nilai selisih mutlak menunjukkan bahwa perlindungan hukum hanya mampu memoderasi tingkat keseriusan kecurangan dan tidak mampu memoderasi komitmen organisasi, personal cost of reporting dan sikap profesionalisme terhadap intensi auditor melakukan tindakan whistle-blowing.
\end{abstract}

Kata kunci: intensi whistle-blowing, komitmen organisasi, personal cost of reporting, tingkat keseriusan kecurangan, sikap profesionalisme, perlindungan hukum 


\section{PENDAHULUAN}

Skandal akuntansi dan bangkrutnya perusahaan-perusahaan besar seperti Enron, World.com, Global, Crossing dan Typo menyebabkan "krisis dalam akuntansi" (Arens et al., 2008). Hal ini menyebabkan kepercayaan masyarakat terhadap profesionalisme dan perilaku etis profesi akuntan saat ini dipertanyakan karena kasus-kasus skandal besar masalah keuangan yang dilakukan oleh perusahaan-perusahaan besar melibatkan kantor akuntan besar serta tokoh-tokoh pelaku akuntansi. Seiring dengan berkembangnya kompleksitas bisnis dan semakin terbukanya peluang usaha dan investasi menyebabkan risiko terjadinya kecurangan pada perusahaan dan lembaga pemerintahan semakin tinggi. Salah satu cara mencegah pelanggaran akuntansi sehingga dapat mengembalikan kepercayaan masyarakat adalah dengan menerapkan teknik pemeriksaan fraud dimana dalam akuntansi forensik dikenal dengan tindakan whistle-blowing atau pemanfaatan whistleblower (Merdikawati dan Andry, 2012).

Whistle-blowing adalah pelaporan yang dilakukan oleh anggota organisasi aktif maupun nonaktif mengenai pelanggaran, tindakan ilegal atau tidak bermoral kepada pihak di dalam maupun di luar organisasi (Khan, 2009). Whistle-blowing telah menarik perhatian dunia saat ini. Banyak perusahaan besar melakukan kecurangan dan akhirnya terungkap dengan bantuan whistle-blowing tersebut (Mustapha dan Siaw, 2012). Di Indonesia, kasus mengenai kecurangan yang akhirnya terbongkar juga terjadi pada institusi pemerintahan. Seperti kasus Gayus Tambunan yang merupakan pegawai di Direktorat Jenderal Pajak yang terlibat dalam kasus penggelapan pajak dan akhirnya terungkap oleh pernyataan Susno Duadji (Sulistomo dan Prastiwi, 2012).

Whistle-blowing adalah masalah organisasi kontroversial. Seseorang yang berasal dari internal organisasi umumnya akan menghadapi dilema etis dalam memutuskan apakah harus "meniup peluit" atau membiarkannya tetap tersembunyi. Dibutuhkan keberanian dan keyakinan untuk melakukannya sehingga beberapa whistleblower menerima pujian heroik (Johnson, 2003). Dimana sebagian orang memandang whistleblower sebagai pengkhianat yang melanggar norma loyalitas organisasi, sebagian lainnya memandang whistleblower sebagai pelindung heroik terhadap nilai-nilai yang dianggap lebih penting dari loyalitas kepada organisasi (Rothschild dan Miethe, 1999). Selain itu, whistleblower dapat membantu organisasi memperbaiki produk yang tidak aman atau menyediakan sumber informasi penting dalam mempertahankan kinerja organisasi yang kompleks (Miceli dan Near, 1985). Whistleblower dapat bertindak dalam penegakan keadilan ketika mengekspos kesalahan perusahaan (Miceli dan Near, 1985). Pandangan yang bertentangan tersebut kerap menjadikan calon whistleblower berada dalam kebimbangan menentukan sikap yang pada akhirnya dapat mendistorsi intensi melakukan tindakan whistle-blowing.

Whistle-blowing merupakan suatu tindakan ketidaksetiaan, tergantung juga pada hubungan antara pelaku dan whistleblower. Memang, sebagian besar pelapor perusahaan menghadapi hasil negatif sebagai akibat dari tindakan mereka: balas dendam, penugasan, menembak, dan pribadi distress Dyck et al. (2010) dan seperti "pemberontak moral" yang sering dikucilkan (Minson dan Monin, 2011). Seorang whistleblower tidak menutup kemungkinan akan mendapatkan terror dari oknum-oknum yang tidak menyukai keberadaaanya (Sulistomo dan Prastiwi, 2012). Lainnya wistleblower menghadapi balas dendam dari komunitas mereka (Dyck et al., 2010).

Tidak banyak orang yang bersedia mengambil risiko untuk melaporkan suatu tindak pidana jika dirinya, keluarganya dan harta bendanya tidak mendapat perlindungan dari ancaman yang mungkin timbul karena laporan yang dilakukan. Begitu juga dengan saksi apabila tidak mendapat perlindungan yang memadai tidak akan memberikan keterangan sesuai dengan fakta yang dialami, dilihat dan dirasakan. Seorang 
peniup peluit (whistleblower) atau pengungkap fakta kasus-kasus tertentu kepada publik akan menanggung segala konsekuensinya. Bagi sebagian orang, hal itu menjadi sebuah siksaan pribadi yang membutuhkan keteguhan hati dan keberanian (Dempster, 2006). Para pengungkap fakta (whistleblowers) kerapkali menghadapi serangan balik dari pihak-pihak yang merasa dirinya diserang, maka sudah sepatutnya hukum memberikan penghargaan dan perlindungan kepada pengungkap fakta ini.

Pengaduan dari whistleblower terbukti lebih efektif dalam mengungkap fraud dibandingkan metode lainnya seperti audit internal, pengendalian internal maupun audit eksternal (Sweeney, 2008). Pendapat tersebut sejalan dengan Report to The Nation yang diterbitkan oleh Association of Certified Fraud Examiners (ACFE) setiap dua tahun sekali yang senantiasa menempatkan tips dalam peringkat teratas sumber pengungkap kecurangan. Pentingnya keberadaan whistle-blowing dalam mengungkapkan kecurangan atau skandal keuangan telah banyak terbukti di awal dekade abad kedua puluh satu (Dyck et al., 2010). Efektivitas whistle-blowing dalam mengungkapkan kecurangan laporan keuangan tidak hanya diakui oleh akuntan dan regulator di Amerika Serikat, namun juga di negaranegara lain (Patel, 2003). Mengingat pentingnya peran whistle-blowing dalam mengungkapkan kecurangan keuangan, maka pemahaman atas faktor-faktor yang mendasari niat untuk melaporkan kecurangan atau penyalahgunaan aset merupakan topik yang sangat penting (Bame-Aldred et al., 2007).

Penelitian sebelumnya yang berkaitan dengan faktor yang memengaruhi intensi tindakan whistle-blowing telah mengungkap beberapa determinan. Penelitian yang dilakukan oleh (Winardi, 2013) dengan menggunakan kerangka theory of planned behavior untuk menjelaskan faktor-faktor individual yang membentuk minta atau intensi whistleblowing. Salah satu faktor individual tersebut adalah sikap profesionalisme (attitude to- wards whistle-blowing) yang menurut penelitian Sari dan Laksito (2014), Kreshastuti dan Prastiwi (2014) dan Joneta (2016) tersebut memiliki pengaruh positif terhadap intensi melakukan tindakan whistle-blowing. Selain faktor individual, beberapa penelitian juga mengaitkan faktor situasional seperti tingkat keseriusan kecurangan (Kaplan dan Whitecotton, 2001; Sabang, 2013; Winardi, 2013) dan personal cost of reporting (Kaplan dan Whitecotton, 2001; Winardi, 2013) sebagai faktor yang turut memengaruhi intensi whistle-blowing.

Tindakan whistle-blowing juga dapat dikaitkan dengan prosocial organizational behavior theory. Tindakan whistle-blowing merupakan salah satu bentuk tindakan prososial anggota organisasi untuk menyampaikan arahan, prosedur, atau kebijakan yang menurutnya mungkin tidak etis, ilegal atau membawa bencana bagi tujuan jangka panjang organisasi kepada individu atau badan lainnya yang memiliki posisi untuk melakukan tindakan korektif. Prosocial organizational behavior theory menegaskan bahwa tindakan whistle-blowing seorang pegawai menunjukkan bentuk komitmen pegawai tersebut untuk melindungi organisasinya dari ancaman hal-hal yang tidak etis atau ilegal. Faktor komitmen organisasi tersebut telah digunakan pula dalam penelitian terdahulu (Ahmad et al., 2012). Berdasarkan uraian masalah di atas maka penelitian ini mengangkat 4 (empat) determinan intensi whistle-blowing dengan perlindungan hukum sebagai variabel moderasi yaitu, komitmen organisasi, personal cost of reporting, tingkat keseriusan kecurangan, dan sikap profesionalisme.

Berdasarkan uraian di atas, maka pokok permasalahan dalam penelitian ini, yaitu: 1) Apakah komitmen organisasi berpengaruh terhadap intensi auditor melakukan tindakan whistle-blowing? 2) Apakah personal cost of reporting berpengaruh terhadap intensi auditor melakukan tindakan whistle-blowing? 3) Apakah tingkat keseriusan kecurangan berpengaruh terhadap intensi auditor melakukan tindakan whistle-blowing? 4) Apakah 
sikap profesionalisme berpengaruh terhadap intensi auditor melakukan tindakan whistle-blowing? 5) Apakah perlindungan hukum memoderasi komitmen organisasi, personal cost of reporting, tingkat keseriusan kecurangan, dan sikap profesionalisme terhadap intensi auditor melakukan tindakan whistle-blowing? Tujuan penelitian ini yaitu untuk menguji pengaruh komitmen organisasi, personal cost of reporting, tingkat keseriusan kecurangan, dan sikap profesionalisme terhadap intensi auditor melakukan tindakan whistle-blowing, dan untuk mengetahui perlindungan hukum memoderasi komitmen organisasi, personal cost of reporting, tingkat keseriusan kecurangan, dan sikap profesionalisme terhadap intensi auditor melakukan tindakan whistle-blowing.

\section{TINJAUAN TEORETIS}

\section{Prosocial Organizational Behavior Theory}

Prosocial organizational behavior merupakan perilaku/tindakan yang dilakukan oleh anggota sebuah organisasi terhadap individu, kelompok, atau organisasi yang ditujukan untuk meningkatkan kesejahteraan individu, kelompok, atau organisasi tersebut. Dengan demikian, perilaku prososial tidak seperti perilaku altruistik (Hazzi dan Maldoan, 2012). Menurut Staub yang dikutip oleh Bagustianto dan Nurkholis (2015), bahwa perilaku prososial adalah perilaku sosial positif yang dimaksudkan untuk memberikan manfaat pada orang lain, namun tidak seperti altruisme, pelaku prososial juga dapat memiliki maksud untuk mendapatkan manfaat/keuntungan untuk dirinya juga.

Prosocial organizational behavior menjadi teori yang mendukung terjadinya whistleblowing. Brief dan Motowidlo dalam Bagustianto dan Nurkholis (2015) menyebutkan whistle-blowing sebagai salah satu dari 13 bentuk prosocial organizational behavior. Hal tersebut sejalan dengan pendapat yang menyatakan bahwa tindakan whistle-blowing dapat dipandang sebagai perilaku prososial karena secara umum perilaku tersebut akan memberikan manfaat bagi orang lain atau organisasi disamping juga bermanfaat bagi whistleblower itu sendiri.

\section{Theory of Planned Behavior}

Theory of Planned Behaviour (TPB) adalah teori psikologi yang dikemukakan oleh Icek Ajzen (1991) yang berusaha menjelaskan hubungan antara sikap dengan perilaku. TPB muncul sebagai jawaban atas kegagalan determinan sikap (attitude) dalam memprediksi tindakan/perilaku aktual (actual behavior) secara langsung. TPB membuktikan bahwa intensi (intention) lebih akurat dalam memprediksi perilaku aktual dan sekaligus dapat sebagai proxy yang menghubungkan antara sikap dan perilaku aktual.

Menurut Ajzen (1991), intensi (minat) diasumsikan untuk menangkap faktor motivasi yang memengaruhi sebuah perilaku, yang ditunjukkan oleh seberapa keras usaha yang direncanakan seorang individu untuk mencoba melakukan perilaku tersebut. Lebih lanjut, TPB mempostulatkan bahwa secara konsep intensi memiliki tiga determinan yang saling independen yaitu, sikap terhadap perilaku (attitude towards behaviour), faktor sosial yang disebut norma subjektif (subjective norm), dan persepsi kontrol perilaku (perceived behavioral control). Tingkatan relatif dari ketiga determinan tersebut dapat berbeda-beda dalam berbagai perilaku dan situasi, sehingga dalam pengaplikasiannya mungkin ditemukan bahwa hanya sikap yang berpengaruh pada intensi seseorang melakukan tindakan tertentu. Kondisi lain, sikap dan persepsi kontrol perilaku cukup untuk menjelaskan intensi tersebut, atau bahkan ketiga-tiganya menunjukkan pengaruh sama.

\section{Determinan Intensi Tindakan Whistle- Blowing}

Bouville (2007) mendefinisikan whistleblowing sebagai tindakan, dari seorang pegawai (atau mantan pegawai), untuk mengungkap apa yang ia percaya sebagai perilaku ilegal atau tidak etis kepada manajemen yang lebih tinggi/manajemen puncak (internal whistle-blowing) atau kepada 
otoritas/pihak berwenang di luar organisasi maupun kepada publik (external whistleblowing). Roa (2007) menyebutkan bahwa: $A$ whistleblower is someone in an organization who witnesses behavior by members that is either contrary to the mission of the organization, or threatening to the public interest, and who decidesto speak out publicity about it.

Uraian di atas menunjukkan bahwa peniup peluit adalah seseorang dalam suatu organisasi yang menyaksikan perilaku anggota organisasi yang dapat bertentangan dengan tujuan organisasi. Perilaku anggota organisasi tersebut menjadi ancaman terhadap kepentingan umum atau organisasi, dan peniup peluit memutuskan untuk menyampaikan hal-hal yang dipandang tidak tepat tersebut. Sejalan hal tersebut, whistleblowing system juga dipandang sebagai pencegahan dan identifikasi terhadap kecurangan yang akan terjadi dalam organisasi (Davis, 1996). Sistem whistle-blowing bekerja melalui dua saluran, yaitu internal whistle-blowing dan eksternal whistle-blowing. Internal whistle-blowing adalah whistle-blowing pihak di dalam organisasi atau saluran yang tersedia dalam organisasi (Miceli et al., 2009), sedangkan eksternal whistle-blowing merupakan pengungkapan pihak di luar organisasi (Kaptein, 2011).

Dempster (2006:1) berpendapat bahwa yang dimaksud dengan whistleblower adalah peniup peluit. Disebut peniup peluit karena seperti wasit dalam pertandingan sepak bola atau olah raga lainnya yang meniupkan peluit sebagai pengungkapan fakta di lapangan, atau polisi lalu lintas yang hendak melakukan tilang kepada seseorang di jalan raya karena orang itu melanggar aturan, atau seperti pengintai dalam peperangan zaman dahulu yang memberitahukan kedatangan musuh dengan bersiul, membocorkan atau mengungkapkan fakta kejahatan, kekerasan atau pelanggaran. Intinya, Dempster (2006) menyebut whistleblower sebagai orang yang mengungkapkan fakta kepada publik mengenai sebuah skandal, malapraktik, atau korupsi. Intensi whistle-blowing berbeda dengan tindakan whistle-blowing aktual karena intensi muncul sebelum tindakan whistle-blowing aktual, atau dengan kata lain diperlukan adanya intensi whistleblowing untuk membuat tindakan whistleblowing aktual terjadi (Winardi, 2013). Departemen Pendidikan Nasional (2008:541) mengartikan intensi sebagai maksud, tujuan, atau keinginan atau permohonan khusus yang diajukan. Oxford dictionary of psychology (Coleman; dikutip dalam Christanti, 2008) mendefinisikan intensi sebagai suatu kecenderungan perilaku yang dilakukan dengan sengaja dan bukan tanpa tujuan. Sukirno dan Sutarmanto (2007) menguraikan bahwa intensi merupakan kompetensi diri individu yang mengacu pada keinginan untuk melakukan suatu perilaku tertentu. Secara umum, jika individu memiliki intensi untuk melakukan suatu perilaku maka individu cenderung akan melakukan perilaku tersebut. Sebaliknya, jika individu tidak memiliki intensi untuk melakukan suatu perilaku maka individu cenderung tidak akan melakukan perilaku tersebut.

Theory of planned behavior menguraikan intensi lebih akurat dalam memprediksi perilaku aktual (Ajzen, 1991). Teori tersebut menjelaskan konsep sikap terhadap perilaku (attitude towards behavior) dan norma subjektif (subjective norm) memprediksi intensi yaitu komitmen organisasi, personal cost of reporting, tingkat keseriusan kecurangan, dan sikap profesionalisme. Selain itu, sikap profesionalisme juga mempunyai keterkaitan dengan prosocial organizational behavior theory. Teori prosocial organizational behavior menegaskan bahwa tindakan/perilaku yang dilakukan oleh anggota sebuah organisasi terhadap individu, kelompok atau organisasi yang ditujukan untuk meningkatkan kesejahteraan individu, kelompok atau organisasi tersebut (Brief dan Motowidlo, 1986). Dengan demikian, kedua teori tersebut mempunyai 4 (empat) determinan yang dapat memengaruhi intensi melakukan tindakan whistle-blowing, yaitu komitmen organisasi, personal cost of reporting, tingkat keseriusan kecurangan, dan sikap profesionalisme. 


\section{Komitmen Organisasi}

Mowday et al. (1979) mendefinisikan komitmen organisasi sebagai kekuatan relatif identifikasi dan keterlibatan individu dalam organisasi tertentu yang dapat ditandai dengan tiga faktor terkait yaitu: pertama, keyakinan yang kuat dan penerimaan terhadap tujuan dan nilai-nilai organisasi; kedua, kesediaan untuk mengerahkan usaha yang cukup atas nama organisasi; dan ketiga, keinginan yang kuat untuk mempertahankan keanggotaan dalam organisasi (loyalitas). Karyawan yang ber komitmen terhadap organisasi akan menunjukkan sikap dan perilaku positif terhadap lembaganya, karyawan akan memiliki jiwa untuk tetap membela organisasinya, berusaha meningkatkan prestasi, dan memiliki keyakinan yang pasti untuk mewujudkan tujuan organisasi (Kuryanto, 2012). Komitmen terhadap organisasi merupakan sikap yang merefleksikan loyalitas karyawan pada organisasi dan proses berkelanjutan dimana anggota organisasi mengekspresikan perhatiannya terhadap organisasi dan keberhasilan serta kemajuan yang berkelanjutan serta komitmen yang muncul bukan hanya bersifat loyalitas yang pasif, tetapi juga melibatkan hubungan yang aktif dengan organisasikerja yang memiliki tujuan memberikan segala usaha demi keberhasilan organisasi yang bersangkutan.

\section{Personal Cost of Reporting}

Personal cost of reporting adalah pandangan pegawai terhadap risiko pembalasan/ balas dendam atau sanksi dari anggota organisasi, yang dapat mengurangi intensi pegawai untuk melaporkan wrongdoing (Schutlz et al., 1993). Anggota organisasi yang dimaksud dapat saja berasal dari manajemen, atasan, atau rekan kerja. Beberapa pembalasan dapat terjadi dalam bentuk tidak berwujud (intangible), misalnya penilaian kinerja yang tidak seimbang, hambatan kenaikan gaji, pemutusan kontrak kerja, atau dipindahkan ke posisi yang tidak diinginkan (Curtis, 2006). Tindakan balasan lainnya mungkin termasuk langkah-langkah yang diambil organisasi untuk melemahkan proses pengaduan, isolasi whistle-blower, pencemaran karakter dan nama baik, mempersulit atau mempermalukan whistle-blower, pengecualian dalam rapat, penghapusan penghasilan tambahan, dan bentuk diskriminasi atau gangguan lainnya (Parmerlee et al., 1982). Sabang (2013) juga menambahkan bahwa personal cost of reporting bukan hanya dampak tindakan balas dendam dari pelaku kecurangan, melainkan juga keputusan menjadi pelapor dianggap sebagai tindakan tidak etis, misalnya melaporkan kecurangan atasan dianggap sebagai tindakan yang tidak etis karena menentang atasan.

\section{Tingkat Keseriusan Kecurangan}

Anggota organisasi yang mengamati adanya dugaan wrongdoing/kecurangan akan lebih mungkin untuk melakukan whistle-blowing jika wrongdoing/ kecurangan tersebut serius (Miceli dan Near, 1985). Organisasi akan terkena dampak kerugian yang lebih besar dari wrongdoing yang lebih serius dibandingkan dari wrongdoing yang kurang serius (Winardi, 2013). Persepsi tiap anggota organisasi terhadap tingkat keseriusan kecurangan dapat saja berbeda antara satu dengan yang lainnya. Pembentuk persepsi tingkat keseriusan kecurangan selain berkaitan dengan besaran nilai kecurangan, juga tidak dapat dipisahkan dari jenis kecurangan yang terjadi. Miceli et al. (1991) mengatakan bahwa anggota organisasi mungkin memiliki reaksi yang berbeda terhadap berbagai jenis kecurangan.

\section{Sikap Profesionalisme}

Profesi dan profesionalisme dapat dibedakan secara konseptual seperti dikemukakan oleh Lekatompessy (2003). Secara sederhana, profesionalisme berarti bahwa auditor wajib melaksanakan tugastugasnya dengan kesungguhan dan kecermatan. Profesionalisme merupakan suatu atribut individual yang penting tanpa melihat apakah suatu pekerjaan merupakan suatu profesi atau tidak. Arens et al. (2008:78) mendefinisikan profesionalisme sebagai 
tanggung jawab individu untuk berperilaku yang lebih baik dari sekedar mematuhi undang-undang dan peraturan masyarakat yang ada. Setiap profesional berpegang pada nilai moral yang mengarahkan dan mendasari perbuatan luhur. Dalam melakukan tugas profesi, para profesional harus bertindak objektif, artinya bebas dari rasa malu, sentimen, benci, sikap malas dan enggan bertindak. Profesionalisme juga merupakan elemen dari motivasi yang memberikan sumbangan pada seseorang agar mempunyai kinerja tugas yang tinggi.

\section{Perlindungan Hukum}

Para whistleblower sangat rentan akan intimidasi dan ancaman bahkan cenderung menjadi sasaran kriminalisasi sebagai pelaku kejahatan yang dikualifikasi sebagai tindak pidana pencemaran nama baik dan perbuatan tidak menyenangkan, sehingga akhirnya mereka dituntut dan dihukum, padahal mereka adalah kunci dari pemberantasan korupsi. Perlindungan hukum bagi pelapor (whistleblower) sangat penting diberikan mengingat peran seorang pelapor (whistleblower) bisa mempermudah mengungkap tindak pidana yang terjadi. Instrumen perlindungan terhadap pelapor (whistle blower) diatur dalam UNCAC (United Nation Convention Against Corruption), UndangUndang Nomor 31 Tahun 2014 tentang Perlindungan Saksi dan Korban Revisi Undang-Undang Nomor 13 tahun 2006, Undang-Undang Pemberantasan Tindak Pidana Korupsi Nomor 20 Tahun 2001, Surat Edaran Mahkamah Agung Nomor 04 Tahun 2011, dan Peraturan Bersama Kemenkumham, Jaksa Agung, Kepala Kepolisian, KPK, dan LPSK Nomor 4 Tahun 2011 tentang Perlindungan Bagi Saksi Pelapor, Pelapor, dan Pelaku yang Bekerja Sama.

\section{Pengaruh Komitmen Organisasi terhadap Intensi Tindakan Whistle-Blowing}

Pegawai yang memiliki komitmen organisasi yang tinggi di dalam dirinya akan timbul rasa memiliki organisasi (sense of belonging) yang tinggi sehingga ia tidak akan merasa ragu untuk melakukan whistleblowing karena ia yakin tindakan tersebut akan melindungi organisasi dari kehancuran. Beberapa penelitian terdahulu menghasilkan temuan yang berlawanan berkaitan dengan pengaruh komitmen organisasi terhadap intensi melakukan tindakan whistleblowing. Penelitian (Somers dan Casal, 1994) menemukan bahwa komitmen organisasi berpengaruh terhadap intensi melakukan tindakan whistle-blowing pada anggota National Association of Accountant (NAA). (Bagustianto dan Nurkholis, 2015) mengemukakan bahwa penelitian tersebut responden yang diklasifikasikan dalam tingkatan berkomitmen organisasi moderat memiliki kecenderungan untuk melaporkan wrongdoing paling tinggi dibandingkan yang memiliki komitmen organisasi rendah ataupun tinggi. Hasil berbeda diperoleh pada penelitian Mesmer-Magnus dan Viswesvaran (2005) yang menemukan bahwa komitmen organisasi tidak memiliki korelasi/keterkaitan dengan intensi whistle-blowing. Penelitian Ahmad et al. (2012) juga menunjukkan bahwa komitmen organisasi tidak mampu untuk menjelaskan intensi perilaku whistleblowing internal auditor di Malaysia. Berdasarkan penjelasan di atas dan hasil-hasil penelitian sebelumnya, maka hipotesis pertama yang diajukan:

$\mathrm{H}_{1}$ : Komitmen organisasi berpengaruh positif terhadap intensi auditor melakukan tindakan whistle-blowing.

\section{Pengaruh Personal Cost terhadap Intensi Tindakan Whistle-Blowing}

Semakin besar persepsi personal cost of reporting seseorang maka akan semakin berkurang intensi orang tersebut untuk melakukan tindakan whistle-blowing. Personal cost of reporting dapat saja didasarkan pada penilaian subjektif (Curtis, 2006), yang artinya persepsi/ekspektasi personal cost of reporting antara pegawai dapat saja berbeda bergantung penilaian masing-masing. Anggota organisasi yang kehilangan pekerjaannya atau mendapatkan gangguan setelah melaporkan wrongdoing mungkin akan 
memandang pelaporan sebagai tindakan yang harus dibayar mahal dan dihukum. Oleh karena itu, tindakan whistle-blowing akan merupakan fungsi persepsi (ekspektasi) individu bahwa kemungkinan tindakan whistle-blowing akan menghasilkan outcome seperti perhatian manajemen terhadap keluhan, upaya penghentian wrongdoing, serta tidak ada pembalasan.

Penelitian yang dilakukan oleh MesmerMagnus dan Viswesvaran (2005) menunjukkan bahwa ancaman pembalasan memiliki hubungan/korelasi negatif dengan intensi untuk melakukan tindakan whistle-blowing. Penelitian Kaplan dan Whitecotton (2001) juga menunjukkan bahwa personal cost of reporting merupakan prediktor signifikan terhadap intensi auditor untuk melaporkan auditor lainnya yang melakukan pelanggaran aturan profesional (dalam bentuk client employment). Temuan mengejutkan datang dari penelitian Winardi (2013) yang menyimpulkan bahwa ternyata variabel personal cost of reporting tidak mampu menjadi faktor yang menjelaskan intensi tindakan whistle-blowing pada pegawai negeri tingkat bawah. Berdasarkan penjelasan di atas dan hasil-hasil penelitian sebelumnya, maka hipotesis kedua yang diajukan:

$\mathrm{H}_{2}$ : Personal cost of reporting berpengaruh negatif terhadap intensi auditor melakukan tindakan whistle-blowing.

\section{Pengaruh Tingkat Keseriusan Kecurangan terhadap Intensi Tindakan Whistle- Blowing}

Ukuran keseriusan kecurangan dapat bervariasi. Beberapa penelitian terdahulu menggunakan perspektif kuantitatif untuk mengukur keseriusan kecurangan. Schultz el al. (1993) dan Menk (2011) menerapkan konsep materialitas dalam konteks akuntansi, sehingga keseriusan kecurangan diukur berdasarkan variasi besarnya nilai wrongdoing/kecurangan/kerugian akibat kecurangan. Perspektif kuantitatif tersebut merupakan pendekatan yang paling mudah dilakukan karena indikatornya yang jelas, terukur, dan mudah diamati. Penelitian yang dilakukan oleh Curtis (2006) menggunakan pendekatan kualitatif, seperti kemungkinan wrongdoing dapat merugikan pihak lain. Tingkat kepastian dan keterjadian wrongdoing berkonsekuensi menimbulkan dampak negatif.

Hasil penelitian yang dilakukan Menk (2011) menghasilkan bukti bahwa faktor materialitas permasalahan berpengaruh positif terhadap posisi etis dan sifat kepribadian, dan melalui keduanya secara konsisten menciptakan perbedaan signifikan pada intensi melaporkan permasalah tersebut. Hasil penelitian yang menyimpulkan bahwa tingkat keseriusan wrongdoing secara signifikan berpengaruh positif terhadap intensi whistle-blowing juga ditemukan pada penelitian yang menggunakan responden auditor internal (Inspektorat) Pemerintah Provinsi Sulawesi Selatan (Sabang, 2013), dan pegawai negeri tingkat bawah (Winardi, 2013). Hasil berbeda ditunjukkan dari penelitian Kaplan dan Whitecotton (2001), bahwa persepsi penilaian keseriusan tidak berhubungan dengan intensi auditor untuk melaporkan perilaku mencurigakan (questionable behaviour) dari rekan kerjanya. Berdasarkan penjelasan di atas dan hasilhasil penelitian sebelumnya, maka hipotesis ketiga yang diajukan:

$\mathrm{H}_{3}$ : Tingkat kecurangan berpengaruh positif terhadap intensi auditor melakukan tindakan whistle-blowing.

\section{Pengaruh Sikap Profesionalisme terhadap Intensi Tindakan Whistle-Blowing}

Profesionalisme dilihat dari dimensi kewajiban sosial disebutkan dalam teori deontologi bahwa nilai moral hanya ada ketika seorang bertindak berdasarkan rasa kewajiban, bukan karena tugas dan kewajiban tersebut akan menimbulkan konsekuensi yang baik, dan juga bukan karena halhal tersebut dapat meningkatkan kesenangan. Seorang yang profesional memiliki kesadaran akan tanggung jawab sosial yang tinggi (Sari dan Laksito, 2014). Dengan demikian, semakin tinggi profesionalisme kewajiban sosial maka akan semakin tinggi 
pula intensi melakukan tindakan whistleblowing.

Penelitian yang terkait dengan sikap profesional, yaitu penelitian yang dilakukan oleh Taylor dan Curtis (2010) dengan menggunakan responden penelitian akuntan publik senior. Hasil penelitian tersebut menyatakan bahwa komitmen profesional, secara positif terkait dengan intensi pelaporan. Penelitian Kreshastuti dan Prastiwi (2014) dengan responden auditor pada kantor akuntan publik di semarang, menunjukkan bahwa identitas profesional auditor berpengaruh positif dan signifikan terhadap intensi melakukan whistle-blowing. Penelitian Joneta (2016) dengan responden penelitian auditor independen yang bekerja di KAP menunjukkan hasil yang konsisten, yaitu komitmen profesional berpengaruh positif terhadap intensi melakukan whistle-blowing. Berdasarkan penjelasan di atas, maka hipotesis keempat yang diajukan:

$\mathrm{H}_{4}$ : Sikap profesionalisme berpengaruh positif terhadap intensi auditor melakukan tindakan whistle-blowing.

Komitmen Organisasi, Personal Cost of Reporting, Tingkat Keseriusan Kecurangan, dan Sikap Profesionalisme Dimoderasi Perlindungan Hukum terhadap Intensi Tindakan Whistle-Blowing

Tidak banyak orang yang bersedia mengambil risiko untuk melaporkan suatu tindak pidana jika dirinya, keluarganya dan harta bendanya tidak mendapat perlindungan dari ancaman yang mungkin timbul karena laporan yang dilakukan. Begitu juga dengan saksi apabila tidak mendapat perlindungan yang memadai tidak akan mau memberikan keterangan sesuai dengan fakta yang dialami, dilihat dan dirasakan. Seorang peniup peluit (whistleblower) atau pengungkap fakta kasus-kasus tertentu kepada publik akan menanggung segala konsekuensinya. Bagi sebagian orang, hal itu menjadi sebuah siksaan pribadi yang membutuhkan keteguhan hati dan keberanian (Dempster, 2006:2). Seperti yang dikutip pada latar belakang bahwa sebagian besar pelapor meng- hadapi hasil negatif sebagai akibat dari tindakan mereka. Seorang whistleblower tidak menutup kemungkinan akan mendapatkan teror dari oknum-oknum yang tidak menyukai kebaradaannya, bahkan dianggap sebagai pemberontak moral yang dikucilkan. Dengan demikian, determinan komitmen organisasi, tingkat keseriusan kecurangan, dan sikap profesionalisme yang merupakan faktor yang dianggap berpengaruh positif terhadap intensi whistle-blowing berpotensi mendapatkan dampak negatif ketika melakukan tindakan whistle-blowing tersebut, sehingga dibutuhkan adanya perlindungan hukum yang memadai.

Determinan personal cost of reporting yang menunjukkan ancaman pembalasan mempunyai hubungan/korelasi negatif dengan intensi malakukan tindakan whistleblowing. Dengan adanya perlindungan hukum akan mendorong partisipasi masyarakat ataupun karyawan perusahaan untuk lebih berani melaporkan suatu kecurangan kepada pihak yang dapat menanganinya. Berdasarkan penjelasan di atas, maka hipotesis yang diajukan:

$\mathrm{H}_{5}$ : Perlindungan hukum memoderasi komitmen organisasi terhadap intensi auditor melakukan tindakan whistleblowing.

$\mathrm{H}_{6}$ : Perlindungan hukum memoderasi personal cost of reporting terhadap intensi auditor melakukan tindakan whistleblowing.

$\mathrm{H}_{7}$ : Perlindungan hukum memoderasi tingkat keseriusan kecurangan terhadap intensi auditor melakukan tindakan whistle-blowing.

$\mathrm{H}_{8}$ : Perlindungan hukum memoderasi sikap profesionalisme terhadap intensi auditor melakukan tindakan whistle-blowing.

\section{METODE PENELITIAN}

\section{Jenis Penelitian}

Penelitian ini merupakan jenis penelitian kuantitatif yang menekankan pada pengujian teori-teori melalui pengukuran variabel-variabel penelitian dengan angka dan melakukan analisis data dengan pro- 
sedur statistik (Indriantoro dan Supomo, 1999:12). Berdasarkan karakteristik masalah penelitian, maka penelitian ini diklasifikasikan ke dalam penelitian deskriptif dan kausalitas yang merupakan penelitian terhadap masalah-masalah, berupa fakta saat ini dari suatu populasi tertentu, dan bertujuan menunjukkan arah hubungan antara variabel independen dengan variabel dependen.

\section{Populasi dan Sampel Penelitian}

Populasi penelitian ini adalah auditor Inspektorat di Provinsi Sulawesi Selatan. Populasi atau auditor inspektorat tersebut berjumlah 54 orang (data tahun 2016-2017). Pengambilan sampel atas responden dilakukan secara purposive sampling. Purposive sampling adalah pemilihan sampel berdasarkan penilaian terhadap beberapa karakteristik anggota sampel yang disesuaikan dengan maksud peneliti (Kuncoro, 2014: 139).

Sampel dipilih berdasarkan kriteria tertentu sehingga dapat mendukung penelitian ini. Kriteria sampel yang digunakan dalam penelitian ini adalah: 1) memiliki jabatan fungsional auditor atau jabatan fungsional auditor kepegawaian; 2) memiliki masa kerja sebagai auditor minimal 3 (tiga) tahun.

Auditor dengan masa kerja tiga tahun dipandang telah mempunyai pengalaman dan mengetahui lingkungan organisasinya, serta dipandang cakap menyampaikan informasi yang terkait dengan profesinya. Karyawan yang berpengalaman memiliki kecenderungan yang lebih tinggi untuk melakukan whistle-blowing (Sugara, 2013). Dari populasi auditor inspektorat di Provinsi Sulawesi Selatan sebanyak 54 orang, sampel yang digunakan hanya 33 responden yang memenuhi kriteria yang ditetapkan dalam penelitian ini.

Penetapan kriteria sampel pada jumlah populasi yang kecil dan jenis penelitian ini yang berkualifikasi deskriptif dan kausalitas maka dibutuhkan minimal 30 sampel (Gay dan Diehl: 140-141; dalam Kuncoro, 2014: 126).

\section{Teknik Pengumpulan Data}

Metode pengumpulan data menggunakan kuesioner dari sumber primer, yaitu sumber data yang langsung memberikan data pada pengumpul data (Sugiyono, 2011: 308), sehingga diperoleh data yang relevan, dapat dipercaya, objektif, dan dapat dijadikan landasan dalam proses analisis. Penyebaran kuesioner dilakukan dengan cara mendistribusikan secara langsung kepada responden (sampel). Responden yang tidak memahami (menanyakan) pernyataan-pernyataan tertentu dari kuesioner tersebut, maka peneliti memberikan penjelasan tentang maksud dari pernyataan-pernyataan tersebut.

\section{Operasionalisasi dan Pengukuran Variabel Intensi Melakukan Tindakan Whistle- blowing}

Intensi melakukan tindakan whistleblowing didasarkan seberapa keras usaha yang direncanakan untuk mencoba melakukan whistle-blowing (Ajzen, 1991). Usaha yang dilakukan calon whistleblower dapat berupa rencana melakukan whistle-blowing baik melalui saluran internal maupun saluran eksternal (Bagustianto dan Nurkholis, 2015). Model pengukuran variabel intensi ini mengikuti model kuesioner penelitian Ajzen (1991), Park dan Blenkinsopp (2009), Bagustianto dan Nurkholis (2015), dan Winardi (2013) yang dimodifikasi. Intensi melakukan tindakan whistleblowing terdiri 5 item pernyataan, yaitu: 1) niat untuk melakukan tindakan whistleblowing, 2) keinginan untuk mencoba melakukan tindakan whistle-blowing, 3) rencana untuk melakukan tindakan whistleblowing, 4) usaha keras untuk melakukan internal whistle-blowing, dan 5) usaha keras untuk melakukan eksternal whistle-blowing jika internal whistle-blowing tidak memungkinkan. Intensi melakukan tindakan whistle-blowing diukur menggunakan skala 
likert 5 poin, yaitu sangat tidak baik sampai dengan sangat baik.

\section{Komitmen Organisasi}

Komitmen organisasi merupakan kekuatan relatif identifikasi dan keterlibatan individu dalam organisasi yang ditandai keyakinan kuat dan penerimaan tujuan dan nilai-nilai organisasi, kesediaan mengerahkan usaha yang cukup atas nama organisasi, dan keinginan kuat mempertahankan keanggotaan dalam organisasi (Mowday et al., 1979) Variabel komitmen organisasi mengadopsi indikator komitmen organisasi yang dikemukan oleh Allen dan Mayer (1990), yang juga dimodifikasi dalam bentuk pernyataan. Komitmen organisasi terdiri 3 indikator, yaitu komitmen afektif, komitmen berkelanjutan, dan komitmen normatif. Ketiga indikator komitmen organisasi tersebut dikembangkan menjadi 6 pernyataan. Komitmen organisasi diukur menggunakan skala likert 5 poin, yaitu sangat tidak baik sampai dengan sangat baik.

\section{Personal Cost of Reporting}

Personal cost of reporting merupakan pandangan pegawai terhadap risiko pembalasan atau balas dendam atau sanksi dari anggota organisasi yang mengurangi intensi pegawai untuk melaporkan kecurangan (Schultz et al., 1993) Variabel personal cost of reporting menggunakan 4 kasus hipotesis occupation fraud. Kasus pertama (1) berkaitan dengan penyalahgunaan asset, kasus kedua (2) berkaitan dengan korupsi, kasus ketiga (3) berkaitan dengan fraud laporan keuangan, dan kasus keempat (4) berkaitan dengan pelanggaran kode etik. Kasus occupation fraud yang digunakan dalam penelitian ini disesuaikan dengan kondisi di Indonesia (Septianti, 2013). Personal cost of reporting diukur menggunakan skala likert 5 poin, yaitu sangat tidak baik sampai dengan sangat baik.

\section{Tingkat Keseriusan Kecurangan}

Tingkat keseriusan kecurangan menggunakan perspektif kuantitatif, seperti yang telah dilakukan oleh Schultz et al. (1993), yang menerapkan konsep materialitas dalam konteks akuntansi. Dengan demikian, keseriusan kecurangan diukur berdasarkan variasi besarnya nilai wrongdoing/kecurangan/kerugian akibat kecurangan. Perspektif kuantitatif merupakan pendekatan yang paling mudah dilakukan karena indikatornya yang jelas, terukur, dan mudah diamati. Tingkat keseriusan kecurangan terdiri 4 Indikator. Peryataan berulang terhadap penilaian tingkat keseriusan kecurangan ditujukan untuk menilai konsistensi penilaian tingkat keseriusan kecurangan, dan untuk menghindari bias yang disebab kan perbedaan jenis kecurangan yang digambarkan. Tingkat keseriusan kecurangan diukur menggunakan skala likert 5 poin, yaitu sangat tidak baik sampai dengan sangat baik.

\section{Sikap Profesionalisme}

Profesionalisme merupakan sikap tanggung jawab individu untuk berperilaku lebih baik, bukan sekedar mematuhi undangundang dan peraturan yang berlaku dalam lingkungan masyarakat (Arens et al., 2008: 78). Variabel sikap profesionalisme menggunakan menggunakan 4 indikator yang dimodifikasi berdasarkan konsep yang dikemukakan oleh Kalbers dan Forgaty (1995), yaitu: 1) afiliasi dengan komunitas, 2) tuntutan untuk mandiri, 3) keyakinan terhadap peraturan sendiri atau profesi, dan 4) kepentingan sosial. Sikap profesionalisme diukur menggunakan skala likert 5 poin, yaitu sangat tidak baik sampai dengan sangat baik.

\section{Perlindungan Hukum}

Perlindungan hukum bagi whistleblower yang ada di Indonesia diatur dalam Undang-Undang No. 31 Tahun 2014 tentang Perlindungan Saksi dan Korban. Perlindungan hukum terdiri 5 indikator yang disesuaikan dengan pernyataan Tatawi (2015), bahwa perlindungan saksi dan korban harus mengacu pada kelima asas: 1) penghargaan atas harkat dan martabat manusia, 2) rasa 
aman, 3) keadilan, 4) tidak diskriminatif, dan 5) kepastian hukum. Perlindungan hukum diukur menggunakan skala likert 5 poin, yaitu sangat tidak baik sampai dengan sangat baik.

\section{Teknik Pengujian Hipotesis}

Teknik analisis yang digunakan untuk menguji hipotesis penelitian ini adalah analisis regresi linier berganda dan analisis regresi moderasi dengan pendekatan nilai selisih mutlak dengan persamaan sebagai berikut:

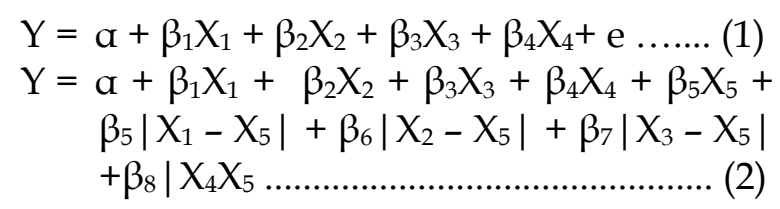

Keterangan:

Y : Intensi melakukan tindakan whistle-blowing

a $\quad$ : Konstanta

$\beta_{1} \ldots \beta_{\mathrm{n}} \quad:$ Koefisien arah regresi

$X_{1} \quad$ : Komitmen organisasi

$\mathrm{X}_{2} \quad$ : Personal cost of reporting

$X_{3} \quad$ : Tingkat keseriusan kecurangan

$\mathrm{X}_{4} \quad$ : Sikap profesionalisme

$X_{5} \quad$ : Perlindungan hukum

$\left|X_{1}-X_{5}\right|$ : Interaksi yang diukur dengan nilai absolut perbedaan antara $\mathrm{X}_{1}$ dan $\mathrm{X}_{5}$

$\left|X_{2}-X_{5}\right|$ : Interaksi yang diukur dengan nilai absolut perbedaan antara $\mathrm{X}_{2}$ dan $\mathrm{X}_{5}$

$\left|X_{3}-X_{5}\right|$ : Interaksi yang diukur dengan nilai absolut perbedaan antara $\mathrm{X}_{3}$ dan $\mathrm{X}_{5}$

$\left|X_{4}-X_{5}\right|$ : Interaksi yang diukur dengan nilai absolut perbedaan antara $\mathrm{X}_{4}$ dan $\mathrm{X}_{5}$

e : Error Term, yaitu tingkat kesalahan penduga dalam penelitian

Hipotesis diuji dengan menggunakan tingkat signifikansi $(\alpha)=0,05$ atau 5\%. Untuk menguji pengaruh komitmen organisasi, personal cost of reporting, tingkat keseriusan kecurangan, dan sikap profesionalisme terhadap intensi melakukan tindakan whistle- blowing dilakukan dengan menguji nilai $\mathrm{t}$ pada tingkat signifikansi $(\alpha)=0,05$. Demikian halnya, pengujian hipotesis yang menunjukkan interaksi (moderasi) perlindungan hukum dengan komitmen organisasi, personal cost of reporting, tingkat keseriusan kecurangan, dan sikap profesionalisme terhadap intensi melakukan tindakan whistleblowing. Jika nilai signifikansi $<0,05$ maka hipotesis diterima, sebaliknya jika nilai signifikansi $>0,05$ maka hipotesis ditolak (tidak dapat diterima).

\section{ANALISIS DAN PEMBAHASAN Gambaran Unit Analisis}

Responden penelitian ini adalah auditor Inspektorat Provinsi Sulawesi Selatan. Kuesioner yang didistribusikan sebanyak 44 kuesioner, namun hanya 33 kuesioner yang dapat dijadikan data penelitian (sampel). Tingkat pengembalian kuesioner (respon rate) sebesar $75 \%$. Sebanyak 11 kuesioner tidak bersyarat dijadikan data penelitian, diantaranya sebanyak 7 tidak kembali dan 4 kuesioner lainnya tidak diisi oleh responden dengan lengkap. Responden penelitian ini sebagian besar berjenis kelamin perempuan, yaitu sebanyak 20 responden $(60,60 \%)$ dan yang berjenis kelamin laki-laki sebanyak 13 responden $(39,40 \%)$. Usia responden sebagian besar berkisar antara 36-45 tahun sebanyak 15 responden $(45,45 \%)$, selanjutnya berusia antara 46-55 tahun sebanyak 12 responden (36,36\%), usia 25-35 tahun yaitu sebanyak 3 responden $(9,09 \%)$, dan berusia lebih dari 55 tahun juga sebanyak 3 responden $(9,09 \%)$. Tingkat pendidikan responden sebagian besar telah menempuh pendidikan S2 sebanyak 19 responden $(57,58 \%)$ dan pendidikan S1 sebanyak 14 responden $(42,42 \%)$. Masa kerja responden sebagian besar telah bekerja selama 3-10 tahun sebanyak 11 responden (33,33\%), selanjutnya telah bekerja selama 20 tahun keatas sebanyak 13 responden $(39,40 \%)$, dan telah bekerja selama 11-20 tahun sebanyak 9 responden $(27,27 \%)$. Adapun profil responden, kategori, dan persentasenya ditunjukkan pada tabel 1 . 
Tabel 1

Profil Responden

\begin{tabular}{llcc}
\hline \hline Profil Responden & \multicolumn{1}{c}{ Kategori } & Frekuensi & Persentase \\
\hline Jenis Kelamin & Laki-laki & 13 & 39,40 \\
& Perempuan & 20 & 60,60 \\
& Total & 33 & 100 \\
Usia & 25 - 35 Tahun & 3 & 9,09 \\
& 36 - 45 Tahun & 15 & 45,45 \\
& 45 - 55 Tahun & 12 & 36,36 \\
& $>$ 55 Tahun & 3 & 9,09 \\
Pendidikan & Total & 33 & 100 \\
& S1 & 14 & 42,42 \\
& S2 & 19 & 57,58 \\
Masa Kerja & Total & 33 & 100 \\
& 3 - 10 Tahun & 11 & 33,33 \\
& 11 - 20 Tahun & 9 & 27,27 \\
& $>$ 20 Tahun & 13 & 39,40 \\
& Total & 33 & 100 \\
\hline
\end{tabular}

Sumber: Data diolah, 2016

\section{Deskriptif Variabel}

Deskripsi variabel penelitian berdasarkan perolehan data 33 responden ditunjukkan pada tabel 2. Tabel 2 menunjukkan bahwa nilai rata-rata tertinggi berada pada variabel komitmen organisasi sebesar 24,52, selanjutnya perlindungan hukum sebesar 20,79, intensi tindakan whistle-blowing sebesar 20,42, sikap profesionalisme sebesar 16,79 , tingkat keseriusan kecurangan sebesar 15,94, dan personal cost of reporting sebesar 13,30. Variabel komitmen organisasi, sikap profesional, dan perlindungan hukum menunjukkan nilai rata-rata sebesar 24,52, 16,79, dan 20,79 yang lebih mendekati angka maksimumnya masing-masing, dibandingkan variabel personal cost of reporting, tingkat keseriusan kecurangan, dan intensi tindakan whistle-blowing.

Tabel 2

Deskriptif Variabel

\begin{tabular}{lccccc}
\hline \hline & N & Minimum & Maximum & Mean & Std. Deviation \\
\hline Komitmen Organisasi & 33 & 18 & 30 & 24.52 & 2.830 \\
Personal Cost of Reporting & 33 & 7 & 20 & 13.30 & 3.779 \\
Tingkat Keseriusan Kecurangan & 33 & 13 & 20 & 15.94 & 1.968 \\
Sikap Profesionalisme & 33 & 12 & 20 & 16.79 & 2.162 \\
Perlindungan Hukum & 33 & 14 & 25 & 20.79 & 2.509 \\
Intensi Tindakan Whistle-blowing & 33 & 17 & 25 & 20.42 & 2.194 \\
Sumber: Data diolah, 2016 & & & & &
\end{tabular}

Responden memiliki tingkat komitmen yang tinggi terhadap organisasinya dan juga sikap profesionalisme yang tinggi, serta keinginan memperoleh perlindungan hu- 
kum yang maksimal. Standar deviasi tertinggi berada pada variabel personal cost of reporting sebesar 3,779, selanjutnya komitmen organisasi sebesar 2,830, perlindungan hukum sebesar 2,509, intensi tindakan whistle-blowing sebesar 2,194, sikap profesionalisme sebesar 2,162, dan tingkat keseriusan kecurangan sebesar 1,968. Responden mempunyai tingkat pemahaman yang sangat beragam terhadap personal cost of reporting dibanding variabel lainnya.

\section{Uji Validitas dan Reliabilitas Data}

Tabel 3 berikut ini menunjukkan bahwa semua item pernyataan variabel komitmen organisasi, personal cost of reporting, tingkat keseriusan kecurangan, sikap profesionalisme, perlindungan hukum, dan intensi tindakan whistle-blowing yang diuji dalam penelitian ini dinyatakan valid dan reliabel. Keseluruhan variabel menunjukkan nilai corrected item-total correlation $>\mathrm{r}$ tabel pada signifikansi $0,05(5 \%)$ dan nilai cronbach's alpha $>0,60$.

Tabel 3

Hasil Uji Kualitas Data

\begin{tabular}{lccc}
\hline \hline \multicolumn{1}{c}{ Variabel } & $\begin{array}{c}\text { Jumlah } \\
\text { Pernyataan }\end{array}$ & $\begin{array}{c}\text { Uji Reliabilitas } \\
\text { Cronbach Alpha } \\
\text { Reliabel jika >0,60 }\end{array}$ & $\begin{array}{c}\text { Uji Validitas } \\
\text { Corrected Item } \\
\text { Total Correlation } \\
\text { Valid jika }>\mathbf{0 , 3 4 4}\end{array}$ \\
\hline \hline Komitmen Organisasi & 6 & 0,745 & $0,393-0,869$ \\
Personal Cost of Reporting & 4 & 0,816 & $0,621-0,905$ \\
Tingkat Keseriusan Kecurangan & 3 & 0,688 & $0,553-0,720$ \\
Sikap Profesionalisme & 4 & 0,724 & $0,631-0,897$ \\
Perlindungan Hukum & 5 & 0.859 & $0,715-0,888$ \\
Intensi Tindakan Whistle-blowing & 5 & 0,791 & $0,614-0,830$ \\
\hline
\end{tabular}

Sumber: Data diolah, 2016

\section{Uji Asumsi Klasik}

\section{Uji Normalitas}

Berdasarkan tabel 4 terlihat bahwa nilai kolmogorov-smirnov Z sebesar 0,860 dengan tingkat signifikan 0,450 . Hal ini menunjuk kan bahwa variabel penelitian terdistribusi secara normal karena berada pada tingkat signifikasinya $0,450>0,05$. Dengan demikian, variabel komitmen organisasi, personal cost of reporting, tingkat keseriusan kecurangan, sikap profesional- isme, perlindungan hukum, dan intensi auditor melakukan tindakan whistle-blowing berdistribusi normal.

Tabel 4

Hasil Uji Normalitas

\begin{tabular}{llc}
\hline \hline & & Unstandardized Residual \\
\hline $\mathrm{N}$ & Mean & 33 \\
Normal Parametersa & Std. Deviation & $0 \mathrm{E}-7$ \\
& Absolute & .99766966 \\
Most Extreme Differences & Positive & .150 \\
& Negative & .089 \\
Kolmogorov-Smirnov Z & & -.150 \\
Asymp. Sig. (2-tailed) & & .860 \\
\hline
\end{tabular}

Sumber: Data diolah, 2016 


\section{Uji Multikoliniearitas}

Berdasarkan hasil pengujian pada tabel 5 di bawah ini, nilai VIF untuk semua variabel memiliki nilai lebih kecil dari 10 dan nilai tolerance lebih besar dari 0,10. Dengan demikian, variabel komitmen organisasi, personal cost of reporting, tingkat keseriusan kecurangan, sikap profesionalisme, perlindungan hukum, dan intensi auditor melakukan tindakan whistle-blowing terbebas (tidak terdapat) gejala multikolinearitas antara variabel independen.

Tabel 5

Hasil Uji Multikolinearitas

Coefficients $^{\mathrm{a}}$

\begin{tabular}{lcc}
\hline \multirow{2}{*}{ Model } & \multicolumn{2}{c}{ Collinearity Statistics } \\
\cline { 2 - 3 } & Tolerance & VIF \\
\hline \hline Komitmen Organisasi & 0.477 & 2.096 \\
Personal Cost of Reporting & 0.846 & 1.182 \\
Tingkat Keseriusan Kecurangan & 0.360 & 2.781 \\
Sikap Profesionalisme & 0.381 & 2.624 \\
1 Perlindungan Hukum & 0.435 & 2.301 \\
\hline
\end{tabular}

a. Dependent Variable: IntensiI

Sumber: Data diolah, 2016

\section{Uji Heteroskedastisitas}

Grafik scatterplot di bawah ini terlihat bahwa sebaran titik-titik menyebar secara acak dan tersebar baik di atas maupun di bawah angka 0 pada sumbu Y. Hal ini dapat disimpulkan bahwa tidak terjadi heteroskedastisitas pada model regresi yang digunakan dalam penelitian ini.

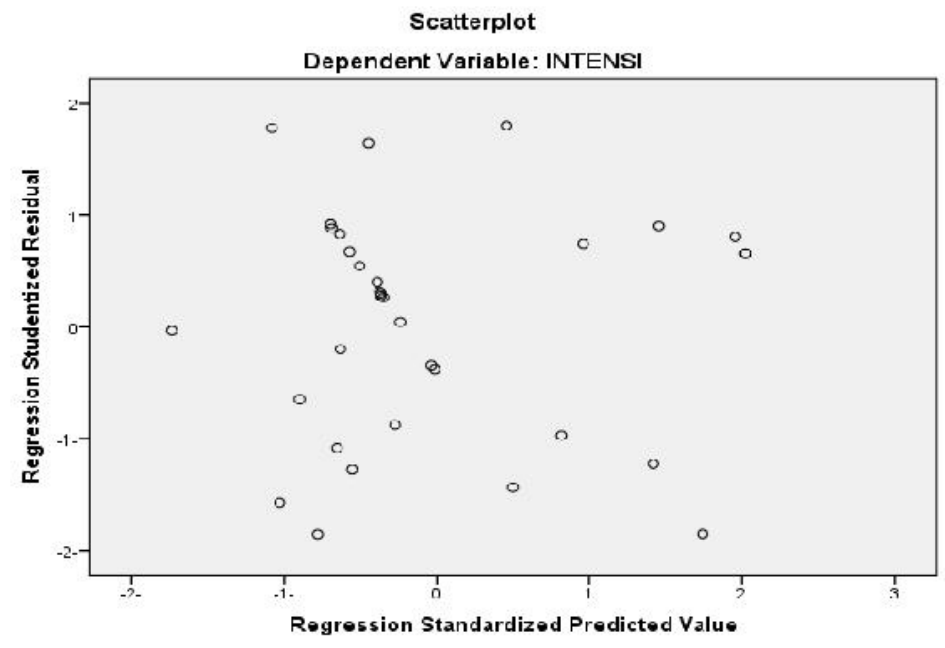

Sumber: Data diolah, 2016

\section{Gambar 1 \\ Grafik Scatterplot}

\section{Hasil Pengujian Hipotesis \\ Koefisian Determinasi}

Tabel 6 berikut ini menunjukkan bahwa nilai $\mathrm{R}^{2}$ sebesar 0,638 , hal ini berarti bahwa
$63,8 \%$ intensi auditor melakukan tindakan whistle-blowing dipengaruhi oleh variabel komitmen organisasi, personal cost of reporting, tingkat keseriusan kecurangan, dan 
sikap profesionalisme. Sisanya sebesar 36,2\% dipengaruhi oleh variabel lain yang tidak diteliti dalam penelitian ini.

\section{Uji Kelayakan Model}

Berdasarkan hasil uji anova atau uji kelayakan model pada tabel 7 menunjukkan bahwa nilai $F$ sebesar 15,071 dan nilai signifikansi sebesar 0.000. Dengan demikian, model penelitian ini layak untuk digunakan, sehingga pengujian secara parsial dapat dilanjutkan.

\section{Uji Regresi Linier Berganda}

Penelitian ini konsisten menggunakan confidence level $95 \%$. Dengan demikian, nilai statistik pada tabel 8 menunjukkan bahwa personal cost of reporting dan komitmen organisasi tidak berpengaruh signifikan terhadap intensi auditor melakukan tindak an whistle-blowing. Di sisi lain, tingkat keseriusan kecurangan dan sikap profesionalisme berpengaruh signifikan terhadap intensi auditor melakukan tindakan whistleblowing.

Tabel 6

Koefisien Determinasi $\left(\mathbf{R}^{2}\right)$

\begin{tabular}{lccccc}
\hline Model & R & R Square & Adjusted R Square & \multicolumn{2}{c}{ Std. Error of the Estimate } \\
\hline 1 & $.826^{\text {a }}$ & 0.683 & 0.638 & & 1.321 \\
\hline a. & Predictors: (Constant), Sikap & Profesionalisme, & Personal & Cost of Reporting, & Tingkat \\
Keseriusan Kecurangan, Komitmen Organisasi. & & & & \\
Sumber: Data diolah, 2016 & & & & &
\end{tabular}

Tabel 7

Hasil Uji Kelayakan Model (F)

ANOVA $^{\mathrm{a}}$

\begin{tabular}{rrrrrrr}
\hline \hline & Model & Sum of Squares & \multicolumn{1}{c}{ Df } & Mean Square & F & \multicolumn{1}{c}{ Sig. } \\
\hline \multirow{2}{*}{1} & Regression & 105.199 & 4 & 26.300 & 15.071 & $.000^{\mathrm{b}}$ \\
& Residual & 48.862 & 28 & 1.745 & & \\
& Total & 154.061 & 32 & & & \\
\hline
\end{tabular}

a. Dependent Variable: Intensi

b. Predictors: (Constant), Sikap Profesionalisme, Personal Cost of Reporting, Tingkat Keseriusan Kecurangan, Komitmen Organisasi

Sumber: Data diolah, 2016

Tabel 8

Hasil Uji Regresi Linier Berganda

Coefficients $^{\mathrm{a}}$

\begin{tabular}{|c|c|c|c|c|c|c|}
\hline & \multirow{2}{*}{ Model } & \multicolumn{2}{|c|}{$\begin{array}{l}\text { Unstandardized } \\
\text { Coefficients }\end{array}$} & \multirow{2}{*}{$\begin{array}{c}\begin{array}{c}\text { Standardized } \\
\text { Coefficients }\end{array} \\
\text { Beta } \\
\end{array}$} & \multirow[t]{2}{*}{$\mathbf{t}$} & \multirow[t]{2}{*}{ Sig. } \\
\hline & & $\mathbf{B}$ & Std. Error & & & \\
\hline \multirow{5}{*}{1} & (Constant) & 6.752 & 2.666 & & 2.532 & 0.017 \\
\hline & Komitmen Organisasi & -.026 & 0.118 & -.034 & -.223 & 0.825 \\
\hline & $\begin{array}{l}\text { Personal Cost of Reporting } \\
\text { Tingkat Keseriusan }\end{array}$ & -.091 & 0.065 & -.156 & -1.391 & 0.175 \\
\hline & Kecurangan & 0.551 & 0.161 & 0.494 & 3.425 & 0.002 \\
\hline & Sikap Profesionalisme & 0.401 & 0.171 & 0.395 & 2.34 & 0.027 \\
\hline
\end{tabular}

a. Dependent Variable: Intensi

Sumber: Data diolah, 2016 
Hasil pengujian pada tabel 8 , nilai kolom B baris pertama menunjukkan konstanta (a) dan baris selanjutnya menunjukkan kostanta variabel independen. Hasil pengujian hipotesis secara statistik menunjukkan bahwa koefisien regresi variabel komitmen organisasi -0.026 dengan tingkat signifikansi sebesar 0,825 yang lebih besar dari 0,05 , maka $\mathrm{H}_{1}$ ditolak. Ini berarti komitmen organisasi berpengaruh negatif dan tidak signifikan terhadap intensi auditor melakukan tindakan whistle-blowing. Tidak adanya pengaruh yang signifikan dari komitmen organisasi tehadap intensi auditor melakukan tindakan whistle-blowing dikarenakan adanya faktor yang memengaruhi kepuasan kerja auditor yang dapat berasal dari rekan kerja atau pimpinan oganisasai secara umum, demikian juga yang berkaitan dengan komitmen yang dimiliki auditor. Komitmen yang kuat terhadap organisasi kontras dengan komitmen kolega (rekan kerja), yang meliputi rasa tanggung jawab, keandalan dan kesiapan untuk mendukung rekan-rekan dalam sebuah organisasi serta dalam keadaan tertentu hubungan dari kedua komitmen bisa saling bertentangan dan akan menimbulkan dilema bagi seseorang untuk menentukan arah komitmennya hingga memengaruhi intensi seseorang untuk melaporkan pelanggaran yang terjadi dalam organisasinya. Temuan ini konsisten dengan hasil penelitian Mesmer-Magnus dan Viswesvaran (2005) yang menemukan bahwa komitmen organisasi tidak memiliki korelasi/keterkaitan dengan intensi melakukan tindakan whistle-blowing, dan penelitian Ahmad et al. (2012) yang menunjukkan bahwa komitmen organisasi tidak mampu untuk menjelaskan intensi perilaku whistle-blowing internal auditor di Malaysia.

Variabel personal cost of reporting mempunyai koefisien regresi sebesar -0.091 dan tingkat signifikansi 0,175 yang lebih besar dari 0,05 , maka $\mathrm{H}_{2}$ ditolak. Dengan demikian, personal cost of reporting berpengaruh negatif dan tidak signifikan terhadap intensi auditor melakukan tindakan whistle-blowing. Hal ini disebabkan oleh adanya persepsi auditor sebagai whistleblower potensial bahwa dampak kerugian secara fisik, ekonomi, dan psikologis berpengaruh dalam pembuatan keputusan etis. Sejalan dengan pendapat Sabang (2013) bahwa personal cost of reporting bukan hanya dampak tindakan balas dendam dari pelaku kecurangan, melainkan keputusan menjadi pelapor dianggap sebagai tindakan tidak etis. Menurut Bagustianto dan Nurkholis (2015), personal cost of reporting tidak berpengaruh signifikan terhadap intensi melakukan tindakan whistle-blowing, karena responden dalam penelitian ini (auditor) memiliki karakteristik yang unik. Responden dengan latar belakang pendidikan/pelatihan, pengalaman, dan pekerjaan yang berkaitan dengan audit dalam penelitian ini umumnya telah familiar dengan fraud dan alur/cara penanganannya, oleh karena itu tidak sulit bagi responden untuk memilih jalur pelaporan yang menghindari personal cost of reporting saat akan melakukan whistle-blowing, misalnya melalui upaya whistle-blowing anonim atau melalui internal whistle-blowing system. Melalui mekanisme tersebut, identitas pelapor bisa saja dirahasiakan dan pelapor terlindungi dari risiko personal cost of reporting. Penelitian ini sejalan dengan penelitian Winardi (2013) dan Bagustianto dan Nurkholis (2015) yang menghasilkan kesimpulan yang sama, yaitu personal cost of reporting tidak berpengaruh terhadap intensi melakukan tindakan whistle-blowing. Hasil penelitian ini bertentangan dengan temuan penelitian Mesmer-Magnus dan Viswesvaran (2005) dan Kaplan dan Whitecotton (2001) yang menyatakan bahwa personal cost of reporting memiliki hubungan negatif dan merupakan prediktor signifikan terhadap intensi melakukan tindakan whistle-blowing.

Variabel tingkat keseriusan kecurangan mempunyai koefisien regresi sebesar 0.551 dan tingkat signifikansi 0,002 yang lebih kecil dari 0,05, maka $\mathrm{H}_{3}$ diterima. Hal ini berarti tingkat keseriusan kecurangan ber- 
pengaruh positif dan signifikan terhadap intensi auditor melakukan tindakan whistleblowing. Hasil pengujian ini konsisten dengan penelitian terdahulu (Menk, 2011; Sabang, 2013; Winardi, 2013; Bagustianto dan Nurkholis (2015) yang juga menggunakan konsep materialitas sebagai pembeda tingkat keseriusan kecurangan.

Variabel sikap profesionalisme mempunyai koefisien regresi sebesar 0.401 dan tingkat signifikansi 0,027 yang lebih kecil dari 0,05 , maka $\mathrm{H}_{4}$ diterima. Hal ini berarti sikap profesionalisme berpengaruh positif dan signifikan terhadap intensi auditor melakukan tindakan whistle-blowing. Dengan demikian, hipotesis keempat yang menyatakan sikap profesionalisme berpengaruh positif terhadap intensi auditor melakukan tindakan whistle-blowing terbukti.
Hal ini mencerminkan bahwa profesionalisme yang disandang oleh auditor menjadi salah satu faktor pendorong pada tindakan yang mengedepankan etika. Hasil penelitian ini konsisten dengan penelitian yang dilakukan oleh Taylor dan Curtis (2010), Kreshastuti dan Prastiwi (2014), dan Joneta (2016).

\section{Hasil Uji Regresi Moderasi Nilai Selisih Mutlak}

Hasil uji statistik pada tabel 9 di bawah ini, menunjukkan bahwa variabel perlindungan hukum hanya mampu memoderasi tingkat keseriusan kecurangan terhadap intensi auditor melakukan tindakan whistleblowing. Hal tersebut tampak bahwa $\mathrm{Abs}_{3} \mathrm{X}_{5}$ dengan tingkat signifikan $0,001<$ 0,05 .

Tabel 9

Hasil Uji Regresi Nilai Selisih Mutlak

Coefficients $^{a}$

\begin{tabular}{|c|c|c|c|c|c|c|}
\hline & \multirow{2}{*}{ Model } & \multicolumn{2}{|c|}{$\begin{array}{l}\text { Unstandardized } \\
\text { Coefficients }\end{array}$} & \multirow{2}{*}{$\begin{array}{c}\text { Standardized } \\
\text { Coefficients } \\
\text { Beta }\end{array}$} & \multirow[t]{2}{*}{$\mathbf{t}$} & \multirow{2}{*}{ Sig. } \\
\hline & & B & Std. Error & & & \\
\hline \multirow{5}{*}{1} & (Constant) & 19.500 & 0.400 & & 48.72 & 0.000 \\
\hline & AbsX1_X5 & -.210 & 0.342 & -.070 & -.613 & 0.546 \\
\hline & AbsX2_X5 & 0.238 & 0.257 & 0.098 & 0.925 & 0.365 \\
\hline & AbsX3_X5 & 1.737 & 0.431 & 0.337 & 4.033 & 0.001 \\
\hline & AbsX4_X5 & -.408 & 0.349 & -.123 & -1.170 & 0.254 \\
\hline
\end{tabular}

a. Dependent Variable: Intensi

Sumber: Data diolah, 2016

Hasil uji nilai selisih mutlak yang terlihat pada tabel 9, menunjukkan bahwa variabel moderating $\mathrm{Abs}_{1} \mathrm{X}_{5}$ tidak signifikan dengan nilai koefisien regresi (standardized coefficients) sebesar -0,210 dan angka signifikansi sebesar 0,546 (lebih besar dari 0,05). Variabel perlindungan hukum tidak memoderasi variabel komitmen organisasi terhadap intensi auditor melakukan tindakan whistle-blowing ( $\mathrm{H}_{5}$ ditolak). Justifikasi atas tidak adanya interaksi atau moderasi antara perlindungan hukum dan komitmen organisasi terhadap intensi auditor melakukan tindakan whistle-blowing adalah bahwa auditor yang melakukan tindakan whistle-blowing atas dasar loyalitas terhadap organisasi dengan alasan untuk melindungi organisasi dari kehancuran, atau memilih untuk tidak melakukan tindakan whistle-blowing. Indikasi lainnya, bahwa auditor tidak mempertimbangkan ada atau tidaknya perlindungan hukum karena komitmen organisasi lebih kepada sikap individu auditor itu masing-masing. Hal 
tersebut dijelaskan dalam theory of planned behavior yaitu determinan sikap terhadap perilaku (attitude towards behaviour).

Variabel moderating $\mathrm{Abs}_{2} \mathrm{X}_{5}$ tidak signifikan dengan nilai koefisien regresi (standardized coefficients) sebesar 0,238 dan angka signifikansi sebesar 0,365 (lebih besar dari 0,05). Variabel perlindungan hukum tidak mampu memoderasi variabel personal cost of reporting terhadap intensi auditor melakukan tindakan whistle-blowing $\left(\mathrm{H}_{6}\right.$ ditolak). Justifikasi yang dapat menjelaskan atas tidak memoderasinya tersebut adalah perlindungan hukum bagi whistle-blower tergolong masih lemah sesuai dengan pernyataan Eddy (2010) menyatakan bahwa Pasal 10 Ayat (2) UU No.13 Tahun 2006 adalah bertentangan dengan semangat whistleblower, karena pasal ini tidak memenuhi prinsip perlindungan terhadap seorang whistleblower, dimana yang bersangkutan tetap akan dijatuhi hukuman pidana bilamana terlibat dalam kejahatan tersebut dan terbukti melakukan kesalahan dan ketentuan pasal tersebut bersifat kontra legem dengan ayat (1) dalam pasal dan undang-undang yang sama, pada hakikatnya menyebutkan bahwa saksi, korban, dan pelapor tidak dapat dituntut secara hukum baik pidana maupun perdata atas laporan kesaksian yang akan, sedang atau telah diberikan. Pasal 10 Ayat (2) tersebut sesungguhnya memberikan perlindungan setengah hati kepada whistleblower (Siahaan, 2015), menimbulkan persoalan yang cukup mendasar dan berpotensi menimbulkan polemik hukum dan polemik kebijakan bagi proses penegakan hukum serta menimbulkan ketidakpastian hukum dan tidak memenuhi rasa keadilan bagi masyarakat dan tidak dapat memberikan perlindungan hukum bagi whistleblower (Karek, 2016).

Variabel moderating $\mathrm{Abs}_{3} \mathrm{X}_{5} \mathrm{X}_{5}$ signifikan dengan nilai koefisien regresi (standardized coefficients) sebesar 1,737 dan angka signifikansi sebesar 0,001 (lebih kecil dari $0,05)$. Hal ini berarti bahwa variabel perlindungan hukum merupakan variabel yang memoderasi tingkat keseriusan kecurangan terhadap intensi auditor melakukan tindakan whistle-blowing, jadi hipotesis ketujuh $\left(\mathrm{H}_{7}\right)$ terbukti atau diterima. Para auditor yang mempunyai persepsi bahwa semua jenis pelanggaran yang terjadi merupakan jenis pelanggaran yang relatif serius dan dapat menimbulkan dampak kerugian yang relatif besar bagi dirinya dan organisasi, oleh karena itu, para whistleblower potensial akan terdorong untuk melaporkan dugaan fraud atau pelanggaran. Memutuskan untuk melaporkan dugaan fraud atau pelanggaran, besar kemungkinan akan menempuh risiko yang sangat tinggi, baik risiko internal maupun risiko eksternal (Karek, 2016). Oleh karena itu, seorang pengungkap fakta (whistleblower) baik sebagai pelapor atau saksi berkepentingan langsung dalam menegakkan kebenaran materil atas suatu peristiwa pidana dan negara dengan berlandaskan undang-undang wajib menjamin pengungkap fakta (whistleblower) dalam proses penegakan hukum tersebut, yakni dengan cara memberikan perlindungan hukum dan perlindungan khusus dari segala bentuk ancaman, intimidasi, dan atau ketakutan.

Variabel moderating $\mathrm{Abs}_{4} \mathrm{X}_{5}$ tidak signifikan dengan nilai koefisien regresi (standardized coefficients) sebesar -0,408 dan angka signifikansi sebesar 0,254 (lebih besar dari 0,05). Variabel perlindungan hukum tidak memoderasi sikap profesionalisme terhadap intensi auditor melakukan tindakan whistle-blowing $\left(\mathrm{H}_{8}\right.$ ditolak). Sebagai seorang akuntan yang profesional maka menjaga kepentingan pemakai laporan keuangan hasil audit menjadi tanggung jawab dan prioitas utama.

Apabila ada kesalahan-kesalahan yang dilakukan oleh rekan auditor atau atasan akan mengusik sikap profesionalitasnya, sehingga dapat memberikan keyakinan untuk mengungkapkan kesalahan tersebut. Dengan demikian, apabila tindakan whistleblowing dilakukan atas dasar rasa tanggung jawab dan menjadi prioritas utama maka perlindungan hukum bukanlah hal yang begitu urgen untuk menjadi pertimbangan 
bagi auditor untuk melakukan tindakan whistle-blowing.

\section{SIMPULAN DAN SARAN}

Pengujian dan analisis regresi linier berganda dan analisis regresi moderasi dengan pendekatan nilai selisih mutlak menunjukkan bahwa model tindakan whistle-blowing dapat digunakan memprediksi intensi auditor melakukan tindakan whistleblowing. Dua variabel independen, yaitu tingkat keseriusan kecurangan dan sikap profesionalisme menjadi faktor yang memengaruhi intensi auditor melakukan tindakan whistle-blowing. Sementara itu, komitmen organiasi dan personal cost of reporting tidak berpengaruh terhadap intensi auditor melakukan tindakan whistle-blowing. Interaksi perlindungan hukum dengan tingkat keseriusan kecurangan berpengaruh terhadap intensi auditor melakukan tindakan whistle-blowing, sehingga perlindungan hukum merupakan variabel moderasi. Interaksi perlindungan hukum dengan komitmen organisasi, personal cost of reporting, dan sikap profesionalisme tidak berpengaruh terhadap intensi auditor melakukan tindakan whistleblowing, sehingga perlindungan hukum bukan merupakan variabel moderasi.

Perlindungan hukum yang diberikan terhadap whistleblower harus benar-benar diwujudkan. Seperti yang kita ketahui bahwa whistleblower yang juga tersangka dalam kasus yang sama tidak dapat dibebaskan dari tuntutan pidana, namun keberaniannya untuk mengungkapkan kejahatan yang terjadi bukanlah hal yang mudah karena harus diperhadapkan dengan berbagai risiko, oleh karena itu, perlindungan hukum wajib dilaksanakan oleh aparat penegak hukum atau aparat keamanan untuk memberikan rasa aman baik fisik maupun mental dari ancaman, gangguan, teror, dan kekerasan dari pihak manapun atau bahkan dibebaskan dari jeratan hukum sesuai dengan United Nation Convention Against Corruption yang merupakan instrumen hukum internasional tentang perlindungan hukum terhadap whistleblower. Indonesia termasuk salah satu negara yang meratifikasi konvensi tersebut.

Penelitian ini diharapkan menjadi bahan acuan bagi auditor inspektorat, khususnya bagi Inspektorat Provinsi Sulawesi Selatan dalam merancang strategi untuk meningkatkan intensi whistle-blowing pegawainya serta mendesain atau menyempurnakan whistleblowing system pada institusinya dengan memperhatikan faktor-faktor yang memengaruhi intensi melakukan tindakan whistleblowing. Upaya peningkatan intensi melakukan tindakan whistle-blowing dapat dilakukan misalnya melalui pelatihan etika (ethics training) maupun sosialisasi yang komprehensif tentang kecurangan, manfaat whistleblowing, dan tata cara melakukan whistleblowing yang tepat. Melalui upaya tersebut diharapkan meningkatkan kesadaran akan dampak kecurangan yang serius dan meningkatkan respon positif sikap auditor terhadap whistle-blowing.

\section{DAFTAR PUSTAKA}

Ahmad, S., S. G. Malcolm, dan I. Zubaidah. 2012. Internal Whistle-Blowing Intentions: A Study of Demographic and Individual Factors. Journal of Modern Accounting and Auditing 8(11): 1632-1645. Ajzen, I. 1991. The Theory of Planned Behavior. Organizational Behavior and Human Decision Processes 50(2): 179-211.

Allen, N. J. dan J. P. Mayer. 1990. The Measurement and Antecedents of Affective, Continuance and Normative Commitment to the Organization. Journal of Occupational and Organizational Psychology 63(1): 1-18.

Arens, A. A., R. J. Elder, dan M. S. Beasley. 2008. Auditing dan Jasa Assurance. Erlangga. Jakarta.

Bagustianto, R. dan Nurkholis. 2015. FaktorFaktor yang Mempengaruhi Minat Pegawai Negeri Sipil (PNS) untuk Melakukan Tindakan Whistle-Blowing (Studi Pada PNS BPK RI). Ekuitas: Jurnal Ekonomi dan Keuangan 19(2): 276-295.

Bame-Aldred, C., J. T. Sweeney, dan D. L. Seifert. 2007. An Examination of the 
Effectiveness of Sarbanes-Oxley Whistle-Blower Protection. Journal of Forensic Accounting 8: 105-118.

Bouville, M. 2007. Whistle-Blowing and Morality. Journal of Business Ethics 81(3): 579-585.

Brief, A. P. dan S. J. Motowidlo. 1986. Prosocial Organizational Behaviors. Academy of Management Review 11(4): 710 -725 .

Christanti, D. 2008. Sikap ataukah Significant Others yang dapat Mempengaruhi Intensi Membuang Sampah Sesuai Jenisnya. Jurnal Ilmiah Psikologi Manasa 2(2): 129-145.

Curtis, M. B. 2006. Are Audit-related Ethical Decisions Dependent upon Mood? Journal of Business Ethics 68(2): 191-209.

Davis M. 1996. Some Paradoxes of WhistleBlowing. Business and Professional Ethics Journal 15(1): 147-155.

Dempster, Q. 2006. Whistleblower Para Pengungkap Fakta. Elsam. Jakarta.

Departemen Pendidikan Nasional. 2008. Kamus Besar Bahasa Indonesia. Edisi Keempat. PT Gramedia. Jakarta.

Dyck, A., M. Adair, dan Z. Luigi. 2010. Who Blows the Whistle on Corporate Fraud? Journal of Finance 65(6): 2213-2254.

Eddy, O. S. H. 2010. Tetap Dijatuhi Pidana Bilamana Terlibat dalam Kejahatan. Newsletter. Komisi Hukum Nasional (KHN) 10(6).

Hazzi, O. A. dan I. A. Maldoan. 2012. Prosocial Organizational Behaviors: The Lifeline of Organizations. European Journal of Economics, Finance and Administrative Sciences 54: 1450-2275.

Indriantoro, N. dan B. Supomo. 1999. Metodologi Penelitian Bisnis untuk Akuntansi dan Manajemen. Edisi Pertma. BPFE. Yogyakarta.

Johnson, R. A. 2003. Whistle-Blowing: When it Works and Why. Lynne Riener Publishers, Inc. Colorado.

Joneta, C. 2016. Pengaruh Komitmen Profesional dan Pertimbangan Etis terhadap Intensi Melakukan WhistleBlowing: Locus of Control Sebagai
Variabel Moderasi. JOM Fekon 3(1): 735748.

Kalbers, L. P. dan T. J. Fogarty. 1995. Profesionalism and Its Consequences: A Study of Internal Auditors. A Journal of Practice and Theory 14(1): 64-86.

Kaplan, S. E. dan S. M. Whitecotton. 2001. An Examination of Auditors' Reporting Intentions When another Auditor is Offered Client Employment. A Journal of Practice and Theory 20(1): 45-63.

Kaptein, M. 2011. From Inaction to External Whistleblowing: The Influence of the Ethical Culture of Organizations on Employee Responses to Observed Wrongdoing. Journal of Business Ethics 98(3): 513-530.

Karek, R. F. 2016. Perlindungan Hukum terhadap Pengungkap Fakta (Whistleblower) Berdasarkan Undang-Undang No.13 Tahun 2006 Tentang Perlindungan Saksi dan Korban. Lex Administratum IV(4): 29-37.

Khan, M. A. 2009. Auditors and Whistleblowing Law. Accountant Today: 12- 22.

Kreshastuti, D. K. dan A. Prastiwi. 2014. Analisis Faktor-Faktor yang Mempengaruhi Intensi Auditor untuk Melakukan Tindakan Whistle-blowing. Diponegoro Journal of Accounting 3(2): 1-15.

Kuncoro, M. 2014. Metode Riset untuk Bisnis dan Ekonami Bagaimana Meneliti dan Menulis Tesis? Edisi Empat. Erlangga. Jakarta.

Kuryanto, A. D. 2012. Pengaruh Independensi Auditor, Komitmen Organisasi, Gaya Kepemimpinan, dan Pemahaman Good Corporate Governance terhadap Kinerja Auditor Eksternal (Studi pada KAP di Indonesia). Tesis. Fakultas Ekonomi dan Bisnis Universitas Brawijaya. Malang.

Lekatompessy, J. E. 2013. Hubungan Profesionalisme dengan Konsekuensinya: Komitmen Organisasional, Kepuasan Kerja, Prestasi Kerja dan Keinginan Berpindah (Studi Empiris di Lingkungan Akuntan Publik). Jurnal Bisnis dan Akuntansi 5(1): 69-84. 
Menk, K. B. 2011.The Impact of Materiality, Personality Traits, and Ethical Position on Whistle-Blowing Intentions. Disertasi. Program Doctor of Philosophy in Business, Virginia Commonwealth University. Virginia.

Merdikawati, R. dan P. Andry. 2012. Hubungan Komitmen Profesi dan Sosial Antisipatif Mahasiswa Akuntansi dengan Niat Whistle-Blowing. Diponegoro Journal of Accounting 1(1): 1-10.

Mesmer-Magnus, J. R. dan C. Viswesvaran. 2005. Whistleblowing in Organizations: An Examination of Correlates of Whistle-Blowing Intentions, Action, and Retalation. Journal of Business Ethics 62(3): 277-297.

Miceli, M. P. dan J. P. Near. 1985. Characteristics of Organizational Climate and Perceived Wrongdoing Associated with Whistle-Blowing Decisions. Personnel Psychology 38(3): 525-544.

Miceli, M. P., J. P. Near, dan C. R. Schwenk. 1991. Who Blows the Whistle and Why? Industrial \& Labor Relation Review 45(1): 113-130.

Miceli, M. P., J. P. Near, dan T. M. Dworkin. 2009. A Word to the Wise: How Managers and Policy-Makers can Encourage Employees to Report Wrongdoing. Jurnal of Business Ethics 86(3): 379-396.

Minson, J. A. dan B. Monin. 2011. Do-Gooder Derogation: Disparaging Morally Motivated Minorities to Defuse Anticipated Reproach. Social Psychological and Personality Science 3(2): 200-207.

Mowday, R. T., R. M. Steers dan L. W. Porter. 1979. The Measurement of Organizational Commitment. Journal of Vocational Behavior 14(2): 224-247.

Mustapha, M. dan L. S. Siaw. 2012. Whistle Blowing: Perceptions of Future Accountants. International Conference on Economics Business Inovation 38: 135- 139.

Park, H. dan J. Blenkinsopp. 2009. WhistleBlowing as Planned Behaviour-A Survey of South Korean Police Officer. Journal of Business Ethics 85(4): 545-556.
Parmerlee, M. A., J. P. Near, dan T. C. Jensen. 1982. Correlates of Whistleblowers' Perceptions of Organizational Retaliation. Administrative Science Quarterly, 27(1): 17-34.

Patel, C. 2003. Some Cross-Cultural Evidence on Whistle-Blowing as an Internal Control Mechanism. Journal of International Accounting Research 2(1): 69-96.

Peraturan bersama Kemenkumham, Jaksa Agung, Polri, KPK, dan LPSK No. 4 Tahun 2011 Tentang perlindungan bagi saksi pelapor, pelapor, dan pelaku yang bekerjasama.

Roa, F. C. 2007. Business Ethis and Social Responsibility. First Edition. Philippine Copyright. Manila.

Rothschild, J. dan T. D. Miethe. 1999. Whistle-Blower Disclosures and Management Retaliation. Work and Occupations 26(1): 107-128.

Sabang, M. I. 2013. Kecurangan, Status Pelaku Kecurangan, Interaksi IndividuKelompok, dan Minat menjadi Whistleblower (Eksperimen pada Auditor Internal Pemerintah. Tesis. Fakultas Ekonomi dan Bisnis Universitas Brawijaya. Malang.

Sari, D. N. dan H. Laksito. 2014. Profesionalisme Internal Auditor dan Intensi Melakukan Whistleblowing. Diponegoro Journal of Accounting 03(03): 2337-3806.

Schultz-Jr, J. J., D. A. Johnson, D. Morris, dan S. Dyrnes. 1993. An Investigation of The Reporting of Questionable Acts in an Inter Setting. Journal of Accounting Research 31: 75-103.

Septianti, W. 2013. Pengaruh Faktor Organisasional, Individual, Situasional, dan Demografis terhadap Niat Melakukan WhistleBlowing Internal. Prosiding. Simposium Nasional Akuntansi XVI, Manado.

Siahaan, B. 2015. Kajian Yudiris Tentang Saksi Pengungkap Fakta (WhistleBlower). Lex Crimen IV(1): 178-187.

Somers, M. J. dan J. C. Casal. 1994. Organizational Commitment and Whistle- 
blowing: A Test of The Reformer and The Organizational Man Hypotheses. Group E Organization Management 93(3): 270-284.

Sugara, Y. 2013. Profesionalisme Internal Auditor dan Intensi Melakukan Whistleblowing. Jurnal Liquidity 2(1): 3444 .

Sugiyono. 2011. Metode Penelitian Pendidikan. Alfabeta. Bandung.

Sukirno, R. S. H. dan H. Sutarmanto. 2007. Faktor-Faktor yang Mempengaruhi Intensi Membeli Produk Wayang Kulit pada Masyarakat Suku Jawa. Psikologika 24: 119-131.

Sulistomo, A. dan A. Prastiwi. 2012. Persepsi Mahasiswa Akuntansi terhadap Pengungkapan Kecurangan (Studi Empiris Mahasiswa Akuntansi UNDIP dan UGM). Eprints Undip: 1-28.

Surat Edaran Mahkamah Agung No. 04 Tahun 2011 tentang Perlakuan Bagi Pelapor Tindak Pidana (Whistleblower) dan Saksi Pelaku yang Bekerjasama (Justice Collaborators) di Dalam Tindak Pidana Tertentu.
Sweeney, P. 2008. Hotlines Helpful for Blowing the Whistle. Financial Executive 24(4): 28-31.

Tatawi, M. L. 2015. Perlindungan Hukum Terhadap Saksi dan Korban (Kajian Undang-Undang No. 31 Tahun 2014). Let Ex Societatis III(7): 41-49.

Taylor, E. Z. dan M. B. Curtis. 2010. An Examnation of the Layers of Workplace Influences in Ethical Judgments: Whistleblowing Likelihood and Perseverance in Public Accounting. Journal of Business Ethics 93(1): 21-37.

Undang-Undang RI No.13 Tahun 2006 Tentang Perlindungan Saksi dan Korban.

Undang-Undang RI No.20 Tahun 2001 Tentang Pemberantasan Tindak Pidana Korupsi.

Undang-Undang RI No.31 Tahun 2014 Tentang Perlindungan Saksi dan Korban.

Winardi, R. D. 2013. The Influence of Individual and Situational Factors on Lower-Level Civil Servants' WhistleBlowing Intention in Indonesia. Journal of Indonesian Economy and Business 28(3): 361-376. 